\title{
Higher Education and Covid-19 Pandemic: Matters Arising and the Challenges of Sustaining Academic Programs in Developing African Universities
}

\author{
Muhammad Muftahu ${ }^{1}$
}

\begin{tabular}{l} 
ARTICLE INF O \\
\hline Article History: \\
Received 27.03.2020 \\
Received in revised form \\
01.08 .2020 \\
Accepted \\
Available online \\
01.10 .2020
\end{tabular}

\begin{abstract}
The purpose of this study is to explore the implications of the Covid-19 pandemic to higher education by identifying matters arising and the challenges of sustaining academic programs with specific attention to developing universities in African context. In carrying out this study, secondary data analysis was conducted wherein systematic literature, policy documents, as well as related models between Covid-19 and Higher Education were reviewed. The findings from study indicated that the Covid-19 pandemic has pushed universities in different nations beyond their limits toward developing appropriate and creative alternatives such as transitioning to remote learning, training of academic staff in the use of online instruction materials and tools and encouraging students to complete their education requirements through online learning in response to the Covid-19 pandemic. The present study explored higher education in the current and post Covid-19 pandemic in the global perspective thus fostering broad scope thereby affecting interpretations and generalizations. Findings from this study can be useful for researchers, policymakers, and university leadership in terms of developing policies and program as well as education contingency measures that can address future pandemic and support sustainable learning. As Covid-19 pandemic is a fairly new research area, this study makes an original contribution to the research base of higher education institutions (HEIs) and beyond the Covid-19 pandemic.
\end{abstract}

(C) IJERE. All rights reserved

Keywords:

Higher Education, COVID-19 Pandemic, Sustainability, Academic programs, Universities.

\section{INTRODUCTION}

Around February of 2020, the whole world was caught by surprise by the unexpected arrival of a virus that has now claimed several innocent lives in different parts of the globe. Originating from China, the coronavirus or Covid-19, is described by Centers for Disease Control and Prevention (CDC) (2019) as an illness caused by a virus that can spread from one person to another. The virus primarily spreads through saliva droplets or discharge from nose which means that if an infected person coughs or sneezes or talks near other people, there is a good chance of infecting them (World Health Organization (WHO) 2020). This means that the virus is spread through close contact with the infected or by touching objects or surfaces with virus and then touching one's mouth, nose and/or eyes (CDC, 2019). Majority of the people infected with Covid-19 will experience mild to severe respiratory illness while there are others who will experience no symptoms at all (asymptomatic) (World Health Organization, 2020).

Accordingly, the virus caused by the Covid-19 is a new one which means that a cure is yet to be developed thereby making the coronavirus a deadly one. As the Covid-19 spread rapidly in different countries worldwide, governments were alarmed because of having little experiencing in dealing with a global virus outbreak because this was just supposed to be happening in biblical stories or movies. Consequently, poor emergency responses were seen in the beginning of the outbreak, particularly in nations with weak and autocratic states, with infected people and death tolls rising continuously as governments worldwide attempt to control the outbreak and prevent the rapid spread of the coronavirus (Nixon, N., Chittick, S. \& Faustino, J. , 2020). Covid-19, as a new virus, has spread rapidly throughout the world thereby becoming a global crisis that affected not just people but every sector in the world. Thus, on March 11, 2020, the World Health Organization has declared Covid-19 as a pandemic (Ducharme, J. , 2020).

As the number of cases rapidly increase, global responses are being implemented including encouraging people to practice social distancing, use protective gears (i.e. face mask), cleanliness and disinfection practices (i.e. hand washing) and implementing total lockdown in several countries. Consequently, Covid-19 has impacted all sectors severely such as the higher education sector.

\footnotetext{
${ }^{1}$ muftahu@usm.my National Higher Education Research Institute, Universiti Sains Malaysia, orcid.org/0000-0002-8689-8258
} 
Particularly, universities in developing African countries are more vulnerable to the consequences of the Covid-19 pandemic. According to the International Association of Universities (IAU) (2020), developing African universities are still attempting to transform and improve their higher education system and the Covid-19 pandemic poses a risk of destabilizing the higher education sector with severe consequences. In order to prevent the spread of the pandemic, African universities and college institutions were required to close following the cancelation of classes. Thus, some initiatives have been launched in few African countries to deal with the impact of Covid-19. For example, in Cameroon, the Head of State universities and higher institutions of learning have been urged to make use of all available tools and resources towards establishing a digital learning mechanism to enable students to continue studying and learning while staying at home (IAU, 2020). Despite this, majority of the developing African countries have only initiated cancellation of classes, stretching academic year to 2021 and resuming lectures and exams by $15^{\text {th }}$ June (IAU, 2020).

Thus, with the closure of higher education institutions worldwide, questions are being raised as to the impact of this response to learning opportunities for the students. According to Rieley, J. (2020), Covid-19 has significantly impacted the foundation of education ecosystem wherein educational institutions worldwide are currently struggling towards identifying options available to them in dealing with the impact of the pandemic. Therefore, Covid-19 contributed to significant changes in the higher education sector that can be viewed to either be opportunities or threats. As highlighted by (Cuaton, G. P. , 2020). the global education system is currently in the process of transforming and adapting to new challenges in light of the Covid-19 pandemic thereby putting the conventional teaching and learning practices to the test. In line with this, the purpose of this study is to assess the impact of the Covid-19 pandemic to higher education by identifying matters arising and the challenges of sustaining academic programs in universities.

\section{Response of Universities to Covid-19 Pandemic}

Covid-19 has considerably redefined how higher education is delivered worldwide. In response to the Covid-19 pandemic, the global higher education institutions have started to change how they operate towards meeting the needs of the students and education staff and professionals. In particular, universities, college campuses and higher education institutions canceled classes and closed their doors in response to the Covid-19 pandemic (Hodge, E. , 2020). In line with this, a number of universities in different countries worldwide have started to shift to online learning in addition to some universities canceling spring breaks and advising international students to return to their home countries (Hodge, E. , 2020).

The global higher education sector is currently working on the continuous development of action plans for universities and college and higher education institutions. Responses to the Covid-19 pandemic are carried out by ensuring that universities have updated information about the pandemic and ensuring that safety practices of school operations are performed such as establishing procedures for sick students, promoting information sharing, planning for continuity of learning and supporting vulnerable populations among others (Bender, L. , 2020). In addition, universities worldwide are responding to the Covid-19 pandemic by joining forces with local, regional and international organizations such as the World Health Organization, research institutes and national governments among others towards the creation of appropriate responses that would enable them to contribute to preventing the spread of Covid-19 whilst ensuring the continuity of learning of students (Richardson, S. , 2020). Thus, several universities worldwide have now shifted to online or remote teaching and learning in order to limit the spread of the virus.

\section{Challenges of Universities}

As the Covid-19 situation continues to develop, legislators and higher education officials are working together in order to address short term and long term impacts of the pandemic to the higher education sector (Smalley, A. , 2020). Yet, the Covid-19 pandemic has left the higher education with immediate and long term challenges particularly in the areas of management, financial (funding), academic, technology and learning opportunities (Igoe, M. \& Chadwick, V. , 2020).

- Management - As universities close their doors and cancel classes, the management has been facing challenges in relation to developing appropriate actions and response initiatives in response to the Covid-19 pandemic. Since several universities are already shifting to online or remote teaching and learning, the management is faced with certain challenges such as online supervision, training of the 
faculty with regards to the use of e-learning tools and resistance from students among others (Nganga, G. , Waruru, M. \& Nakweya, G. , 2020). Therefoe, right leadership and managemebnt with clear and difine responsbilties need to be put in place in order to conferton this challenage Salihu, (2020).

- Funding Uncertainties - Due to the closure of universities and the widespread of Covid-19 which is still unlikely to end soon, universities are facing immediate financial concerns such as funding uncertainties. According to Ferguson, H. T. (2020), budget cuts are to be expected for higher education funding moving forward particularly for public universities mainly because a number of economies are still recovering from the past global financial crisis.

- Academics/ Delivery through Technology - As already noted, several universities have already moved to online or remote education. This means that universities are considering challenges with regards to the quality of online instructions delivered through technology (Smalley, A. , 2020).

- Students/ Learning Remotely - In addition to concerns in the delivery of instructions through technology, universities also face challenges in the shift to online or remote learning. According to Rao, K. \& Giuli, C. (2010), learning remotely can contribute to certain challenges for students such as issues with technology (i.e. poor or no internet connection), lack of knowledge on basic computer skills, overwhelming online assignments and coursework and refusal to accept remote learning design because of being used to the conventional classroom learning.

- Technology Acceptance and Adoption - Academics and students face challenges with regard to technology acceptance and adoption because there are some who find the remote learning environment too difficult (Lim, B-C.Y., Sam, H.K. \& Wah, T. K. , 2008). This means that some academics and students are not comfortable with the adoption of technology towards facilitating remote learning due to unfamiliarity thereby influencing technology acceptance behaviors. Some of the academic staff and students are not ready for drastic changes in their education system design (Flavell, H. , Harris, C. , Price, C. , Logan, E. \& Peterson, S. , 2019).

\section{Sustainability of University Education}

Among the concerns raised in time of the Covid-19 pandemic is the sustainability of university education. The pandemic created a highly challenging economic circumstances that threatens the sustainability of university education. For example, it is likely that funding uncertainties draw lack of support for university courses thereby threatening the sustainability of university education (Universities UK , 2020). The Covid-19 pandemic has also showcased the need for universities to develop more flexible learning approaches. The pandemic has prompted all universities worldwide to close and to cancel classes which impacted about 80 per cent of the student population worldwide (Martin, M. \& Furiv, U. , 2020). The same authors explained that there are some universities that managed to offer distance learning or online education but majority of universities were unprepared to have immediate responses to mitigating consequences of the total lockdown caused by Covid-19. This means that the higher education systems lacks the leadership ability to provide diverse learning pathways towards supporting sustainable university education (Salihu M. J. , Nayel M. R. \& Rabiatul-Adawiah A. R. , 2020).

\section{What Developing African Universities Need to do Differently}

Even prior to the Covid-19 crisis, the UNESCO International Institute for Education Planning has already launched some initiatives toward promoting flexible learning pathways to support sustainable learning practices. Yet, the emergence of the pandemic has raised gaps in achieving sustainable development goal (SDG) 4 and realizing the education related targets in the 2030 Sustainable Development Agenda and the protection of education (sdg4education2030.org 2020). In light of the recent events, universities could have developed a more flexible learning pathway such as offering both conventional and remote education to students (Kaup 2020). For example, universities could have restructured their educational platform to promote learning through classroom teaching four times a day (Mon-Thu) and allot one day for online classes (Fri). This type of university education system could have prepared universities for providing immediate responses to the closure of universities resulting from the Covid-19 pandemic. 
In addition, universities could have drafted required online courses for university students based on their course curriculum or majors as part of their mitigation strategy of developing learning continuity programs (Davis, E. \& Berry, C., 2020). This could have encouraged technology acceptance and adoption thereby making transition to online learning environment smoother and with less resistance from students and staff. In addition, this could have led to universities investing in and enhancing their online learning capabilities making online tools available in dealing with the Covid-19 crisis. In relation to this, universities should have started to require academic staff to attend technical workshops and trainings in order to prepare them for handling online courses or using online materials and tools. However, Salihu, M. J. (2019a) encourage that universities should consider their typologies, diversities, as well as their differentiations in designing the required policy and practice framework towards doing all these, thus discouraging the practice of copy and paste of educational policies.

\section{Rising to the Challenges}

As governments and institutions worldwide attempt to mitigate the Covid-19 impacts, universities are starting to pick up the pace towards rising to the challenges. This also entails encouraging students, education staff and parents to rise with them to the Covid-19 challenge through voluntary works, coordinating Covid-19 support drives and leading transformation towards virtual learning environment among others (University of California San Francisco (UCSF) Medical Education , 2020). In addition, Lim, M. (2020) asserted that having a whole university approach is required to encourage embracing technology enhanced learning or remote learning. As transitioning quickly to remote learning is one of the main challenges of universities in response to the Covid-19 pandemic, universities are rising to the challenge by preparing a roadmap in relation to supporting continuity and sustainability of learning. As such, universities are already implementing support services and maximizing online learning opportunities (Sahu, P. , 2020). Several universities have already started training their academic staff in support of their transition to online learning. However, there may be some challenges in terms of access to needed technology thereby posing serious threat to the quality of online education. According to Truong, D. (2020), in some states, commissioners are already urging internet companies to provide internet access for students who do not have the tools for remote learning. In some countries, learning materials are being uploaded on Google Classroom and some universities are already expanding chatbot use in order to answer students' questions about Covid-19 (Truong, D. , 2020; Kelly, R. , 2020). As such, this is a major concern that must be addressed by legislators. Nearly every university worldwide is currently transitioning to online education in rising to the Covid-19 challenge. Certainly, achieving all these lies on the right leadership framework and implantation at the universities level (Salihu, M. J. , 2019b).

\section{Changes in Universities Beyond Covid-19 Pandemic}

While the world is currently facing challenges resulting from the Covid-19 pandemic, changes in universities have started to become evident with the suspension of classroom learning and transitioning to remote learning. As such, the Covid-19 pandemic has influenced the way universities reshape education systems. According to Tam, G. \& Diana El-Azar (2020), universities have developed new educational solutions that could bring much needed innovation that can fuel the future direction of universities worldwide. In addition to this, the same authors also noted that new shifts in education approaches can shape how students are educated and how academic staff teach in the long run. In line with this, universities have already led the way in responding to the Covid-19 pandemic by making unaccustomed shift towards complete online instruction (Rizvi, S. A. T. \& Eckel, P. , 2020). Thus, with all efforts and investments that went to implementing remote education shifts, universities will find it challenging to go back to conventional face to face classroom instruction beyond Covid-19 pandemic.

Aside from the rapid transition to online education, universities will also experience changes in teaching styles and learning behaviors of students beyond the Covid-19 pandemic. According to Yates, D. (2020), online learning should only be considered as an alternative to accommodate missed classes during the Covid-19 pandemic but not as a mainstay in university teaching platforms because there are several issues in the implementation of online learning. Yates explained that while the shift to remote learning promotes continuity of learning, changing the education system altogether beyond Covid-19 will less likely become effective in fostering quality education. In addition to this, education abroad will also most likely change beyond Covid-19 pandemic. Whalen, B. (2020) noted that as the world recovers from the Covid-19 
pandemic in the future, universities will become more creative in their attempt to apply online learning for students from abroad including virtual internships.

\section{Conclusion and Recommendation}

Covid-19 has significantly impacted the higher education systems worldwide. This research was aimed at exploring the impact of the Covid-19 pandemic to higher education by identifying matters arising and the challenges of sustaining academic programs in universities. Findings from this study indicated that the Covid-19 pandemic has pushed universities in different nations such as in developing African countries beyond their limits toward developing appropriate and creative alternatives such as transitioning to remote learning, training academic staff in the use of online instruction materials and tools and encouraging students to complete their education requirements through online learning in response to the Covid-19 pandemic. Despite the launch of these alternatives, African universities are still facing unique challenges such as providing technology (i.e. internet, laptops, etc.) access to students who do not have resources, lack of knowledge and skills of academic staff in basic computer know how and resistance to accept technology adoption and remote learning by some academic staff and students. This suggests that whilst other developing nations worldwide have already started rolling out sustainable and innovative solutions such as carrying out digital learning or online classes, developing African nations are lagging behind in the development and implementation of initiatives to improve higher education digital capabilities and continuously promote learning. Yet, universities are currently devising contingency plans and mitigation efforts towards rising to the challenges caused by the Covid-19 pandemic. The global lockdown of universities as an immediate response to Covid-19 pandemic has caused disruption in learning but also influenced opportunities to pursue remote and distance learning as well as immediate and long term changes that can transform the overall education system beyond the Covid-19 pandemic for the better. Based on best practices from higher education institutions and universities in other developing countries, it is recommended for African universities and higher education institutions to consider inventing in improving their technology infrastructure to strengthen internet capabilities in order to initiate policy implementation regarding the introduction of online education in African universities.

\section{References}

Anderson, R. M. , Heesterbeek, H., Klinkenberg, D. \& Hollingsworth, T. D. (2020). How will country-based mitigation measures influence the course of the COVID-19 epidemic? https://www.thelancet.com/journals/lancet/article/PIIS0140-6736(20)30567-5/fulltext accessed 21 April 2020.

Bender, L. (2020). Key messages and actions for COVID-19 prevention and control in schools. https://www.who.int/docs/default-source/coronaviruse/key-messages-and-actions-for-covid-19prevention-and-control-in-schools-march-2020.pdf?sfvrsn=baf81d52_4, accessed 21 April 2020.

CDC (2019). What you should know about COVID-19 to protect yourself and others. https://www.cdc.gov/coronavirus/2019-ncov/downloads/2019-ncov-factsheet.pdf, accessed 21 April, 2020.

Cuaton, G. P. (2020). Philippine higher education institutions in the time of COVID-19 Pandemic.Working Paper No. 001, DOI: 10.13140/RG.2.2.12511.61603.

Davis, E. \& Berry, C. (2020). Mitigating COVID-19 impacts and getting education systems up and running again: Lessons from Sierra Leone. https://www.globalpartnership.org/blog/mitigating-covid-19impacts-and-getting-education-systems-and-running-again-lessons-sierra, accessed 21 April, 2020.

Ducharme, J. (2020). World Health Organization declares COVID-19 a 'Pandemic.' Here's What That Means. https://time.com/5791661/who-coronavirus-pandemic-declaration/, accessed 21 April 2020.

Ferguson, H. T. (2020). Cuts expected for state higher education funding in the wake of COVID-19. https://www.nasfaa.org/news-

item/21469/Cuts_Expected_for_State_Higher_Education_Funding_in_the_Wake_of_COVID-19, accessed 21 April 2020. 
Flavell, H. , Harris, C. , Price, C. , Logan, E. \& Peterson, S. (2019). Empowering academics to be adaptive with eLearning technologies: An exploratory case study. Australasian Journal of Educational Technology, Vol. 35, No. 1, 1-15.

Hodge, E. (2020). The impact of Coronavirus on Higher Education. https://www.keystoneacademic.com/news/the-impact-of-coronavirus-on-higher-education, accessed 21 April 2020.

Igoe, M. \& Chadwick, V. (2020). After the pandemic: How will COVID-19 transform global health and development?. Retrieved from https://www.devex.com/news/after-the-pandemic-how-will-covid19-transform-global-health-and-development-96936, accessed 11 May 2020.

International Association of Universities (IAU) (2020). The Impact of Covid-19 on Higher Education Worldwide - Resources for Higher Education Institutions. Retrieved from https://www.iauaiu.net/IMG/pdf/covid-19_and_he_resources.pdf, accessed 11 May, 2020.

Kelly, R. (2020). University expands Chatbot use to handle students' Coronavirus questions. https://campustechnology.com/articles/2020/04/14/university-expands-chatbot-use-to-handlestudents-coronavirus-questions.aspx, accessed 21 April, 2020.

Lim, B-C.Y. , Sam, H.K. \& Wah, T. K. (2008). Acceptance of e-learning among distance learners: A Malaysian perspective. Proceedings ascilite Melbourne, 2008, 541-551.

Lim, M. (2020). Educating despite the Covid-19 outbreak: lessons from Singapore. https://www.timeshighereducation.com/blog/educating-despite-covid-19-outbreak-lessonssingapore\#survey-answer, accessed 21 April 2020.

Martin, M. \& Furiv, U. (2020). COVID-19 shows the need to make learning more flexible. https://www.universityworldnews.com/post.php?story=20200324115802272, accessed 21 April 2020

Nganga, G. , Waruru, M. \& Nakweya, G. (2020). Universities face multiple challenges in wake of COVID-19 closures. https://www.universityworldnews.com/post.php?story=20200407162549396, accessed 21 April 2020.

Nixon, N., Chittick, S. \& Faustino, J. (2020). Pivoting to respond to COVID-19: early thoughts from the Philippines. https://devpolicy.org/pivoting-to-respond-to-covid-19-early-thoughts-from-thephilippines-20200327/, accessed 21 April, 2020.

Rao, K. \& Giuli, C. (2010). Reaching REMOTE learners: Successes and challenges for students in an online graduate degree program in the Pacific Islands. International Review of Research in Open and Distance Learning, 11 ( 1), 141-160.

Richardson, S. (2020). Research news roundup: How universities are responding to the COVID-19 pandemic. https://www.exlibrisgroup.com/blog/research-news-covid-19-pandemic-how-universities-areresponding/, accessed 21 April 2020.

Rieley, J. (2020). Coronavirus and its impact on higher education. https://www.researchgate.net/post/Corona_Virus_and_its_impact_on_higher_education, accessed 21 April 2020

Rizvi, S. A. T. \& Eckel, P. (2020). Colleges can help win the war against COVID-19. https://www.insidehighered.com/views/2020/04/02/colleges-can-lead-efforts-against-pandemichave-impact-beyond-campus-borders, accessed 21 April 2020.

Sahu, P. (2020). Closure of universities due to coronavirus disease 2019 (COVID-19): Impact on education and mental health of students and academic staff. https://www.cureus.com/articles/30110-closure-ofuniversities-due-to-coronavirus-disease-2019-covid-19-impact-on-education-and-mental-health-ofstudents-and-academic-staff, accessed 21 April 2020.

Salihu M. J. , Nayel M. R. \& Rabiatul-Adawiah A. R. (2020). Sustainable higher education leadership: A conceptual approach from the functionalist paradigm for higher institutions of learning. Humanities E Social Sciences Reviews- (HSSR), 8, (2), 8 - 12. 
Salihu, M J. (2019b). A conceptual analysis of the leadership theories and proposed leadership framework in higher education. Asian Journal of Education and Social Studies, 5(4): 1-6, 2019. pp 1-7. https://doi.org/10.9734/ajess/2019/v5i430164.

Salihu, M. J. (2019a). An analysis of theory of organisational typologies and their application in higher education institutional settings. Asian Research Journal of Arts \& Social Sciences, 9(4), 1-7. https://doi.org/10.9734/arjass/2019/v9i430149.

Salihu, M. J. (2020). Agencies governing the university education system in Nigeria: An examination of their administrative powers, conflicts and advocacies. ATBU Journal of Science, Technology and Education, 7(4), 231-239.

Smalley, A. (2020). Higher education responses to Coronavirus (COVID-19). https://www.ncsl.org/research/education/higher-education-responses-to-coronavirus-covid-19.aspx, accessed 21 April, 2020.

Sustainable Development Goals-Education (2020). SDG-Education 2030 steering committee urges protection of education, now and post-crisis. https://www.sdg4education2030.org/index.php/sdg-education2030-steering-committee-urges-protection-education-now-and-post-crisis, accessed 21 April, 2020.

Tam, G. \& Diana El-Azar (2020). 3 ways the coronavirus pandemic could reshape education. https://www.weforum.org/agenda/2020/03/3-ways-coronavirus-is-reshaping-education-and-whatchanges-might-be-here-to-stay/, accessed 21 April, 2020.

Truong, D. (2020). As classes move online, what happens to students without internet or computers?https://www.npr.org/local/305/2020/03/18/817691597/as-classes-move-online-whathappens-to-students-without-internet-or-computers, accessed 21 April 2020.

Universities UK (2020). Achieving stability in the higher education sector following COVID-19. https://universitiesuk.ac.uk/news/Documents/uuk_achieving-stability-higher-education-april2020.pdf, accessed 21 April 2020.

University of California San Francisco (UCSF) Medical Education (2020). Students, staff rise to the COVID-19 challenge. https://meded.ucsf.edu/news/students-staff-rise-covid-19-challenge, accessed 21 April 2020.

Whalen, B. (2020). Education abroad in a Post-Covid-19 world. https://www.insidehighered.com/views/2020/04/14/how-covid-19-will-change-education-abroadamerican-students-opinion, accessed 21 April, 2020.

World Health Organization (WHO) (2020). Coronavirus disease 2019 (COVID-19) Situation Report - 73. Retrieved from https://www.who.int/docs/default-source/coronaviruse/situation-reports/20200402sitrep-73-covid-19.pdf, accessed 11 May, 2020.

Worldometers.info (2020). Covid-19 Coronavirus pandemic. https://www.worldometers.info/coronavirus/, accessed 21 April, 2020.

Yates, D. (2020). Online classes \& COVID-19: How will the pandemic affect teachers and teaching?. https://www.researchgate.net/post/Online_classes_COVID

19_How_will_the_pandemic_affect_teachers_and_teaching, accessed 21 April, 2020. 